\title{
Mechanical Performance of Lime Mortar Coatings for Rehabilitation of Masonry Elements in Old and Historical Buildings
}

\author{
Fernando G. Branco ${ }^{1}$, Maria de Lurdes Belgas ${ }^{2}$, Cátia Mendes ${ }^{3}$, Luís Pereira ${ }^{1} \mathbb{D}$ and José Marcos Ortega ${ }^{4, * \mathbb{D}}$ \\ 1 Department of Civil Engineering, Institute for Sustainability and Innovation in Structural Engineering (ISISE), \\ University of Coimbra, 3030-788 Coimbra, Portugal; fjbranco@dec.uc.pt (F.G.B.); lfmpereira@uc.pt (L.P.) \\ 2 Departamental Unit of Engineering, Institute for Sustainability and Innovation in Structural Engineering (ISISE), \\ Instituto Politécnico de Tomar, Quinta do Contador, 2300-313 Tomar, Portugal; lbelgas@ipt.pt \\ 3 Instituto Politécnico de Tomar, Quinta do Contador, 2300-313 Tomar, Portugal; cmendes@ipt.pt \\ 4 Departamento de Ingeniería Civil, Universidad de Alicante, 03080 Alacant/Alicante, Spain \\ * Correspondence: jm.ortega@ua.es; Tel.: +34-96-5903-400 (ext. 2470)
}

check for updates

Citation: Branco, F.G.; Belgas, M.d.L.; Mendes, C.; Pereira, L.; Ortega, J.M. Mechanical Performance of Lime Mortar Coatings for Rehabilitation of Masonry Elements in Old and Historical Buildings. Sustainability 2021, 13, 3281. https://doi.org/ $10.3390 /$ su13063281

Academic Editors: Nicola Masini and Mariateresa Lettieri

Received: 31 December 2020

Accepted: 4 March 2021

Published: 16 March 2021

Publisher's Note: MDPI stays neutral with regard to jurisdictional claims in published maps and institutional affiliations.

Copyright: (c) 2021 by the authors. Licensee MDPI, Basel, Switzerland. This article is an open access article distributed under the terms and conditions of the Creative Commons Attribution (CC BY) license (https:// creativecommons.org/licenses/by/ $4.0 /)$.

\begin{abstract}
The use of lime as a binder in masonry lining mortars plays an important role in its conservation and durability. Knowledge of the mechanical characteristics of pre-existing and restoration mortars is essential in order to guarantee the compatibility between them and for avoiding the appearance of pathologies. The paper mainly focuses on the study of the mechanical performance of lime-based mortars to be applied in rehabilitation works in old buildings. Four types of mortars were tested with very similar workability, based on lime putty, aerial lime, and hydraulic lime. Sand and crushed rock powder were used as aggregates. Compressive and flexural strengths of the mortars were determined, as well as their ultrasonic pulse velocity. Furthermore, specific tests were carried out to characterize the performance of the mortar when used as a binder for plasters and coatings, such as the development of cracking, superficial water absorption under low pressure, and pull-off strength. According to the results obtained, mortars with lime putty showed better mechanical properties, while those with aerial lime had better behavior regarding water absorption under pressure. Despite that, it was generally possible to verify the adequacy of the studied mortars to be used in the rehabilitation of masonry elements.
\end{abstract}

Keywords: coatings; plasters; mortars; lime putty; aerial lime; hydraulic lime; crushed rock powder; mechanical performance; masonry; rehabilitation

\section{Introduction}

Mortars have been used since prehistoric times. The first types of mortar arose by agglutination of different materials, which ensured this basic need. Several transformations occurred over time until the discovery of fire made it possible to observe the effect of heat on limestone and plaster, something that evidenced the substantial improvement in its properties [1].

Lime is one of the oldest binders to be used in construction and was used by ancient Greeks to produce masonry by mixing with sand. Later, Santorini stone, which is a pozzolan (compound rich in silica), was added, thus constituting a hydraulic binder that had as its main characteristic the fact of gaining mechanical strength even underwater [2]. The Romans developed a vast knowledge of lime mortars and pozzolans. Until 79 AD, artificial pozzolans (forehead and carbuncultus) were used, but with the eruption of the Vesuvius volcano, natural ashes were available for use in several great Roman constructions [3].

After the development of Portland cement, lime, which until then was the most used binder for all types of construction, started to have a secondary role, since cement was a more resistant binder, which hardened quickly, thus requiring a shorter time to achieve 
better mechanical performance. Thus, the knowledge on how to produce and apply ancient mortars, as well as the characteristics of these materials was lost over time [4].

Nowadays, one of the main problems registered for buildings is the lack of maintenance, conservation, and rehabilitation interventions. These problems result in the degradation and abandonment of built heritage. In several countries, rehabilitation works in existing buildings have experienced a noticeable increase over the past few decades. This leads to the necessity of assessing the compatibility of modern building materials with the original ones, since harmful by-products may induce severe damage to the adjacent stone blocks $[5,6]$. Research has been carried out around the world, in order to meet these requirements.

The influence of using different materials in lime-based mortars has been studied. Aalil et al. [7] assessed the potential of recycling brick waste to formulate pozzolanic mortars. Mortars produced using aerial lime, sand, and brick dust were characterized. Results showed brick dust exhibits a pozzolanic activity and reduces shrinkage. Moreover, it increases hydric and hygric expansion enhances mechanical strength and affects the color of mortars. An appropriate recipe for restoration mortars could then be proposed to restore regional architectural heritages, depending on the properties of their historic substrates. On the other hand, Thirumalini et al. [8] studied the influence of organic additions on the mechanical properties of lime mortar, and the results showed that loading of organics in the lime mortar decreases the pore size due to the formation of weddellite element in the lime mortar, which fills the gap between two consecutive lime particles. The addition of organics does not reduce total porosity due to the formation of large numbers of smaller size pores in the lime mortar. However, the addition of organics enhanced the mortar strength.

Special attention has been dedicated to the compatibility of lime with different binders. Thus, research aiming at comparing the performance of different binders and characterizing mortars produced with blended binders has been carried out.

In the rehabilitation works of historic masonry, Maravelaki-Kalaitzakiet al. [9] studied the physico-chemical characterization of original mortars and plasters and the evaluation of the repaired ones prepared with natural hydraulic lime (NHL) as binding material and siliceous sand and crushed brick as aggregates. The research included an extensive number of tests to quantify a number of mechanical and physical parameters of the mortars and, after 3 years of intervention with NHL-based mortars and plasters, the success of the interventions was revealed since no cracks or release of soluble salts occurred.

Aggelakopoulou et al. [10] studied the influence of calcium hydrated lime (lime putty or hydrated lime powder) on the chemical and physico-mechanical characteristics of lime mortars. The obtained results revealed that lime powder mortars present a higher carbonation rate and higher values of compressive strength compared to lime putty mortars. Lime powder mortars also exhibit a unimodal pore size distribution (while lime putty mortars present a bimodal one) and higher capillary rise coefficient and porosity accessible to water in respect to lime putty mortars.

Garijo et al. [11] performed a mechanical characterization of natural hydraulic and aerial lime mortars presenting a lime/aggregate ratio of 1:3 and a water/lime ratio of 0.9. Results show that the greatest increase in the mechanical properties of both mortars occurs up to the first 56 days. This increase ranges between $60 \%$ and $90 \%$ of their corresponding value at an age of 448 days depending on the mechanical property and type of mortar. Between day 56 and day 224, there is a more moderate, but progressive evolution. However, after day 224, the evolution of the mechanical properties in light of their mean value is very slow for the aerial lime mortar and shows a slight increase for the natural hydraulic mortar. Furthermore, various empirical equations of such behavior over time have been proposed for both mortars.

Faria et al. [12] carried out an experimental study of lime mortars, using dry hydrated lime and two lime putties, to check the existing bibliography referring that mortars made with lime putty with long extinction periods behave better than others made with the current dry hydrated limes. They concluded that the use of lime putties with long extinction 
periods in mortars allows better performance, particularly in applicability and resistance to sulfates.

Silva et al. [13] analyzed the potential of blended lime-cement mortars to substitute blended lime-natural hydraulic lime mortars as repair mortars in restoration works. They concluded that cement altered more markedly the mechanical and water transport properties of blended mortars than hydraulic lime, with consequences on compatibility. Results showed that blended lime-cement mortars can be used, but cement content should be higher than $25 \%$ (of total binder mass), so that there is a strength increase at an early age, and lower than $50 \%$, in order to not significantly affect compatibility. However, blended lime mortar with $50 \%$ natural hydraulic lime presented the highest potential for restoration.

Gulbe et al. [14] also studied the influence of cement on the properties of lime mortars. The usage of pure aerial lime binders reduces the water resistance and mechanical durability of the material. They determined that pozzolan additives or cement have to be used in lime mortar. Mixed cement lime mortar (with an increasing amount of cement) were synthesized and their properties tested. Results show that Portland cement can be used as a suitable additive to mortars, to improve their compatibility with the hydraulic and historic mortars.

In another work, Silva et al. [15] studied the influence of hydraulic lime content on the properties of blended lime-hydraulic lime mortars. Mortars composed of aerial lime and different percentages of natural hydraulic lime were tested, and results showed that blended mortars with hydraulic lime contents higher than 25\% exhibited higher initial mechanical strength and water absorption and desorption rates than the aerial lime mortar, with a slight reduction of water vapor permeability. Thus, these mortars were revealed to be more promising to be used as repair mortars than the hydraulic lime ones.

The durability of lime mortars in aggressive environments is still an issue nowadays. Grilo et al. [16] evaluated the mechanical, physical, and microstructural behavior of mortars formulated with natural hydraulic lime NHL3.5 conforming to European Standard EN 459-1, submitted to natural marine environment, humid and standardized conditions, and also the benefits and drawbacks of adding metakaolin in partial replacement of lime. Results showed that mortars with NHL3.5 presented positive results at young ages. The metakaolin addition contributed tothe strength increase and capillary water coefficient decrease, thus improving the performance in an aggressive marine environment.

The curing conditions of the mortars are also a parameter that conditions their performance. Mechanical and mineralogical characteristics of natural hydraulic limemortars with different percentages of lime replacement by metakaolin under different laboratory and natural marine curing conditions have been an object of study [17].

Santos et al. [18] studied the pore structure of air lime mortars, formulated with aggregates of different mineralogy and grain size distribution, to assess the influence of sand type on the microstructural modification over time and establish the relationship between these modifications and the mechanical performance. An optimized grain size distribution of the sand (optimized compactness) proved to be favorable to air lime mortars compared with grain size distribution defined by standard EN 196-1. A relationship between the mechanical properties and the porous structure was established. The assessment of the microstructure indicates that the packing density and the shape of the aggregates are the dominant parameters influencing the pore size distribution of macropores; however, the mineralogy and related characteristics also have an important impact on capillary porosity.

Zhang et al. [19] studied a building material widely used in ancient buildings in Chinese coastal areas, to assess the parameters that influence the properties of shell lime mortar. Results show that the sand-lime and water-lime ratios have major impacts on the disintegration index, shear strength, and compressive strength of shell lime mortar, which can also be enhanced by adding glutinous rice.

To ensure compatibility, it is important to characterize the performance of the materials to be used in the rehabilitation [12]. It is important to know their mechanical performance [20], and also some physical characteristics, such as the hygroscopic behavior. 
Garijo et al. [21] studied the influence of several parameters on the mechanical performance of natural hydraulic lime mortars, to take into account variations in the dosage methodology and production process. Parameters studied included water/binder ratio, mold material, aggregate size and type, and the different curing conditions on mortar performance. The authors propose a number of empirical equations, which can be helpful when simulating numerical models of historical constructions.

The present paper aims at contributing to a better knowledge of lime-based mortars to be applied in rehabilitation works in old buildings. The paper focuses mainly on the mechanical performance of the mortars. Four types of lime mortars were tested with very similar workability. Different aggregates were also taken as variables. Laboratory tests were carried out to quantify direct mechanical parameters, such as the compressive and flexural strength of the mortars. Indirect parameters that may be related to mechanical performances, such as ultrasonic pulse velocity, were also quantified. Then, specific tests were carried out to characterize the performance of the mortar when used as a binder to build masonry walls and also as plaster in wall coverings. The development of cracking, superficial water absorption, and pull-off strength were some of the parameters tested.

The results obtained for all variables took into account are presented are described, analyzed, and commented on. The results are also compared with results from a previously published bibliography. The adequacy of the studied mortars for use in the rehabilitation of old buildings is commented on.

\section{Materials and Methods}

\subsection{Materials}

The materials used for preparing the studied mortars were aerial lime, hydraulic lime, and lime putty as binders, and sand and crushed rock powder as aggregates.

First of all, regarding the aggregates used, the river sand came from the quarry of SEAT (Sociedade Extração Areia do Tejo) located in Guerreira-Santa Cita (Santarém; Portugal) and was provided by the company José Antunes\&Filhos, Lda (Carvalhal—Sertã, Portugal). All the sand was previously passed through a sieve with $4 \mathrm{~mm}$ mesh. The crushed rock powder was supplied by the company Mota Engil, coming from its quarry in Vale dos Ovos-Sabacheira (Portugal), and it was also passed through the $4 \mathrm{~mm}$ mesh sieve.

The grain size distributions of the aggregates, obtained according to the standard NP EN 933-1 [22], are shown in Figure 1. Their maximum $\left(D_{\max }\right)$ and minimum $\left(d_{\min }\right)$ diameters are indicated in Table 1 . The density of the sand and crushed rock powder used as aggregates, determined according to the standard Portuguese Standard NP EN 1097-6 [23], and their bulk density obtained following the standard NP EN 1097-3 [24], can be also observed in Table 1.

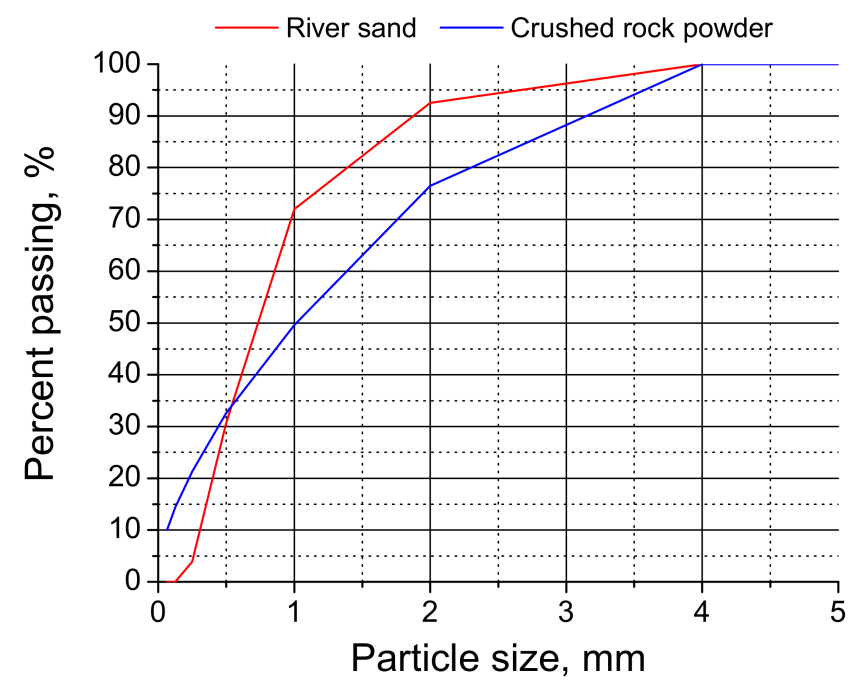

Figure 1. Grain size distribution of sand and crushed rock powder used as aggregates. 
Table 1. Density, maximum, and minimum diameters of aggregates.

\begin{tabular}{ccccc}
\hline Aggregate & $\begin{array}{c}\mathbf{D}_{\text {max }} \\
(\mathbf{m m})\end{array}$ & $\begin{array}{c}\mathrm{d}_{\mathbf{m i n}} \\
\mathbf{( m m )}\end{array}$ & $\begin{array}{c}\text { Density } \\
\left(\mathbf{k g} / \mathbf{m}^{3}\right)\end{array}$ & $\begin{array}{c}\text { Bulk Density } \\
\left(\mathbf{k g} / \mathbf{m}^{\mathbf{3}}\right)\end{array}$ \\
\hline $\begin{array}{c}\text { Sand } \\
\text { Crushed rock powder }\end{array}$ & 2 & 0.250 & 2609 & 1494 \\
\hline
\end{tabular}

In relation to the binders used in the mortars, the lime puttywas provided by the company Aldeias de Pedra Construções, Lda (Vila de Rei, Portugal). The aerial lime used was provided by the company Calcidrata de Alcanede-Santarém (Portugal) and it was classified as CL90 according to NP EN 459-1 [25]. Finally, the hydraulic lime was provided by the company Cimpor. This hydraulic lime was classified as HL5 [25].

\subsection{Sample Preparation}

Four types of mortars have been analyzed in this study. Firstly, a mortar with lime putty and sand, designated as ASPL, as well as a mortar containing aerial lime, hydraulic lime, and sand, named ACL/HL, were prepared. In addition to this, two other kinds of mortars were also made, one of them with aerial lime, sand, and crushed rock powder, designated as ACL/PP, and the other with lime putty, sand, and crushed rock powder, named as ASPL/PP. The preparation of the mortars has been performed according to the standard EN 1015-2 [26], using an automatic mixer.

The application of the mortars studied in this work is for use as masonry coatings in the rehabilitation of old and historical buildings. Therefore, the lime to aggregate ratio adopted for preparing all the specimens was 1:3 (in volume), because this is the most common value of this parameter taken for this particular application [4]. The purpose of this research is to analyze mortars with the same or very similar workability, in order to facilitate their real practical use if adequate mechanical performance is obtained. Then, regarding the amount of water used for manufacturing the mortars, it was determined based on the abovementioned criterion consisting of all the mortars produced, which had the same or very similar workability. The workability was evaluated from the consistency of the studied mortars, determined using the flow table according to standard EN 10153 [27]. The flow value of all the studied mortars was in the range from 145 to $150 \mathrm{~mm}$. Finally, the dosages in volume for each one of the mortars can be observed in Table 2, and their dosage in mass is compiled in Table 3.

Table 2. Dosages in volume for each mortar type.

\begin{tabular}{cccccc}
\hline Mortar Type & Aerial Lime & $\begin{array}{c}\text { Hydraulic } \\
\text { Lime }\end{array}$ & Lime Putty & $\begin{array}{c}\text { Crushed Rock } \\
\text { Powder }\end{array}$ & Sand \\
\hline ASPL & - & - & 1 & - & 3 \\
ACL/HL & 0.5 & 0.5 & - & - & 3 \\
ACL/PP & 1 & - & - & 1 & 2 \\
ASPL/PP & - & - & 1 & 1 & 2 \\
\hline
\end{tabular}

Table 3. Dosages in mass for the studied mortars.

\begin{tabular}{ccccccc}
\hline $\begin{array}{c}\text { Mortar } \\
\text { Type }\end{array}$ & $\begin{array}{c}\text { Aerial } \\
\text { Lime } \\
(\mathbf{g})\end{array}$ & $\begin{array}{c}\text { Hydraulic } \\
\text { Lime } \\
(\mathbf{g})\end{array}$ & $\begin{array}{c}\text { Lime } \\
\text { Putty } \\
(\mathbf{g})\end{array}$ & $\begin{array}{c}\text { Crushed } \\
\text { Rock } \\
\text { Powder } \\
(\mathbf{g})\end{array}$ & $\begin{array}{c}\text { Sand } \\
(\mathbf{g})\end{array}$ & $\begin{array}{c}\text { Water } \\
(\mathbf{m L})\end{array}$ \\
\hline ASPL & - & - & 370 & - & 1380 & 88.58 \\
ACL/HL & 92 & 128 & - & - & 1400 & 300 \\
ACL/PP & 182 & - & - & 475 & 920 & 280 \\
ASPL/PP & - & - & 370 & 475 & 920 & 87.32 \\
\hline
\end{tabular}


The setting of the mortars was carried out in accordance with standard EN 10152 [26]. Two different types of specimens were made. Prismatic samples with dimensions $40 \mathrm{~mm} \times 40 \mathrm{~mm} \times 160 \mathrm{~mm}$ were prepared according to standard EN 1015-11 [28]. Specimens of mortars on ceramic bricks were also prepared. This type of specimen consisted of applying a layer of mortar with $20 \mathrm{~mm}$ thickness on the top surface of a brick with dimensions $300 \mathrm{~mm} \times 200 \mathrm{~mm} \times 90 \mathrm{~mm}$, simulating a coating layer. All the bricks used were moistened using a brush before the application of the mortar (see Figure 2a). In addition to this, a wooden frame, also moistened, was placed on the brick as a formwork to delimit the mortar and allow the application of a layer of a constant thickness (see Figure 2b). After that, the mortar coating was applied on the surface of the brick (see Figure 2c) and it was compacted. Finally, with the help of a board the surface was leveled (see Figure 2d).

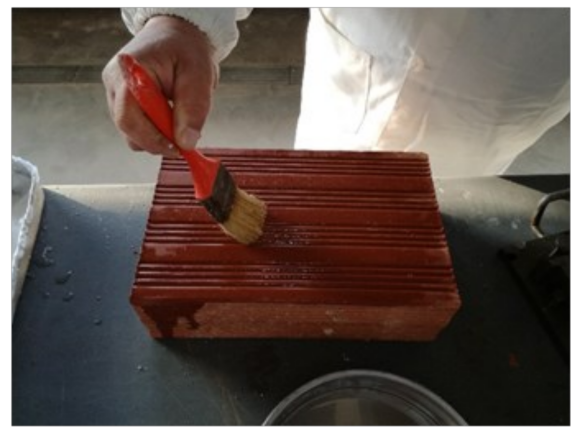

(a)

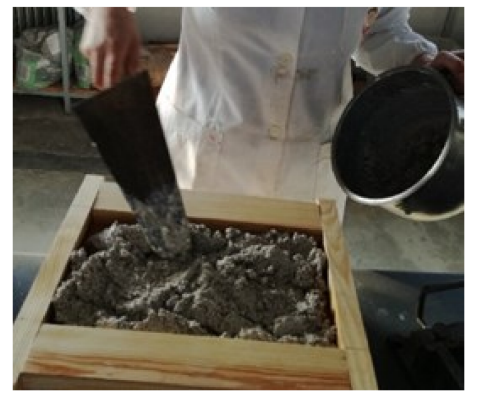

(c)

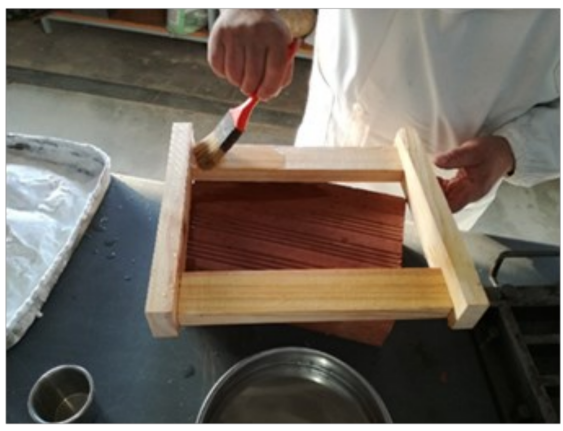

(b)

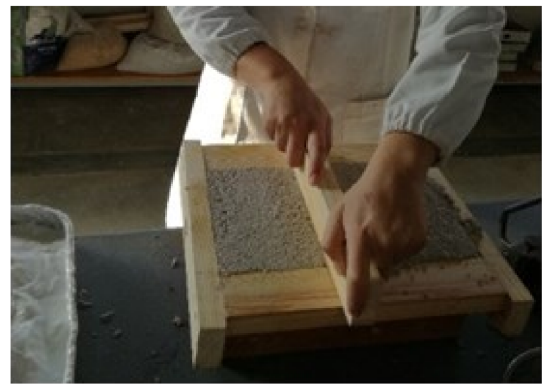

(d)

Figure 2. (a) Moistening of the surface of the brick; (b) detail of the wooden frame used as formwork; (c) application of the mortar coating layer; (d) leveling of the surface using a board.

All the samples were stored in a laboratory condition at $20 \pm 2{ }^{\circ} \mathrm{C}$ temperature and $50 \pm 5 \%$ relative humidity until the latest testing age (90 days).

\subsection{Compressive and Flexural Strength}

The mechanical strengths were determined according to the standard EN 1015-11 [28] in prismatic samples with dimensions $40 \mathrm{~mm} \times 40 \mathrm{~mm} \times 160 \mathrm{~mm}$. The testing machine was a model Servosis ME-402 E (Servosis, Madrid, Spain). For determining the flexural strength, a load cell of $5 \mathrm{KN}$ was used and the test was carried out with the specimens supported on four points. In the case of the compressive strength, the load cell had a force of $200 \mathrm{kN}$. The ductility coefficient defined as the quotient of flexural strength divided by compressive strength was also calculated. For each one of the mortar types studied, both flexural and compressive strength were obtained in three samples at 28 and 90 hardening days. 


\subsection{Pull-Off Test}

The pull-off test allows evaluating the adherence of a coating to the support, according to a perspective of durability and resistance. This test makes it possible to determine the adhesion resistance relative to the maximum strength, applied by direct tension, perpendicular to the mortar surface [29]. The pull-off test was carried out in accordance with standard EN 1015-12 [30] and it was performed in the specimens of mortars on ceramic bricks as a coating layer.

Before starting the test, the position of the three square metallic slabs in the coating was marked ( see Figure 3a). According to other authors [29,31,32], the use of square slabs for this test was chosen, instead of circular ones, due to the fragility of the lime mortars, which could be damaged inside the notches when they are carried out with a crown drill. The square metallic slabs were glued to the mortar coating using a quick epoxy resin manufactured by UHU Company (Bolton Adhesives group, Rotterdam, Nederland). After that, the notches were executed using a circular saw (see Figure 3b) in the mortar coating beside the sides of two of the three square slabs (see Figure 3c), in order to assess the possible differences in the behavior related to pulling in the cases with and without these notches. Finally, the square slabs were pulled out with the equipment for the direct tension test (see Figure 3d).

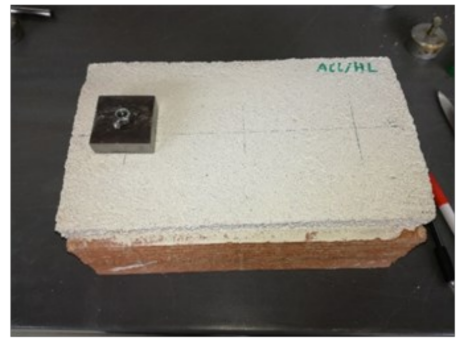

(a)

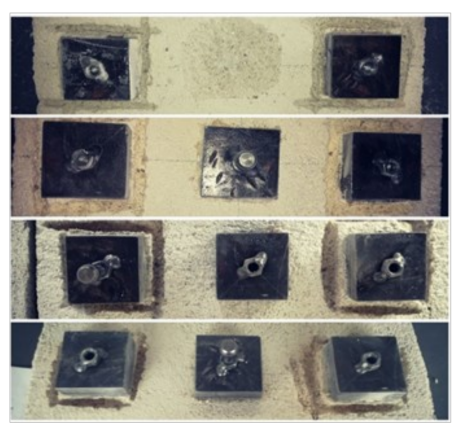

(c)

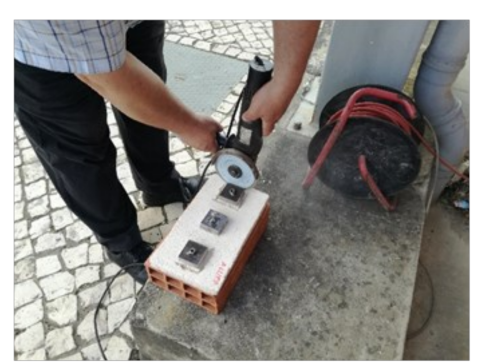

(b)

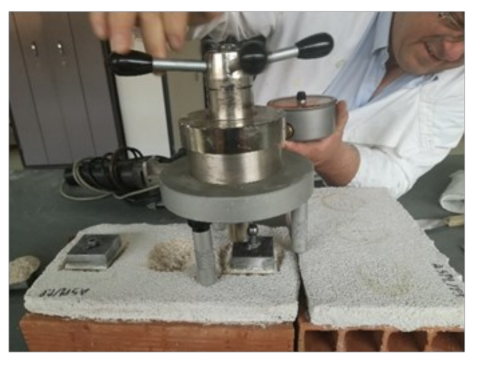

(d)

Figure 3. (a) Marking of the position of the square metallic slabs in the mortar coating of a specimen (one of the slabs is already glued in the coating); (b) execution of the notches using a circular saw; (c) detail of the notches already finished in the perimeter of the left and right square slab, while the central slab was tested without notch; (d) equipment for direct tension test used for pulling out the slabs.

As has been already mentioned, in pull-off tests the strength is usually determined using circular slabs glued to the mortar coating, although in this work square slabs were used. Therefore, it was necessary to make the conversion from the determined pull-off strength for square slabs ( $\left.\sigma_{\text {square }}\right)$ to the equivalent strength for circular ones $\left(\sigma_{\text {circular }}\right)$. The equation used for making this equivalence is shown next:

$$
\sigma_{\text {circular }}=\frac{\sigma_{\text {square }} \times A_{\text {circular }}}{A_{\text {square }}}
$$


where: $\sigma_{\text {circular }}$ is the equivalent pull-off strength for a circular slab glued to the mortar coating $(\mathrm{MPa}), \sigma_{\text {square }}$ is the pull-off strength for a square slab glued to the mortar coating obtained from the test $(\mathrm{MPa}), \mathrm{A}_{\text {circular }}$ is the contact area of a circular slab with a radius equal to $25 \mathrm{~mm}\left(\mathrm{~mm}^{2}\right), A_{\text {square }}$ is the contact area of a square slab with a side of $50 \mathrm{~mm}\left(\mathrm{~mm}^{2}\right)$.

For each one of the mortar types studied, three specimens were tested at 90 hardening days.

\subsection{Ultrasonic Pulse Velocity}

The ultrasonic pulse velocity (UPV) provides information about the mechanical characteristics, the homogeneity, and the presence of cracks and defects in the mortars. This parameter was determined according to the standard NP EN 12504-4 [33] at 90 hardening days. The equipment used was a Pundit manufactured by C.N.S. Electronics LTD. (London, England). The ultrasonic pulse velocity was obtained in prismatic samples with dimensions $40 \mathrm{~mm} \times 40 \mathrm{~mm} \times 160 \mathrm{~mm}$ using direct transmission. This parameter was also determined in the specimens of mortars on ceramic bricks as coating layer using indirect transmission, with both transducers on the surface of the mortar layer. For each mortar type and kind of specimen, three samples were tested and three measurements were taken in the same sample. In addition to this, for specimens of coating mortars on bricks, several measurements were made at different distances $(6,7,9,11,13,15$, and $17 \mathrm{~cm}$, respectively) between the centers of transducers (see Figure $4 a, b$ ).

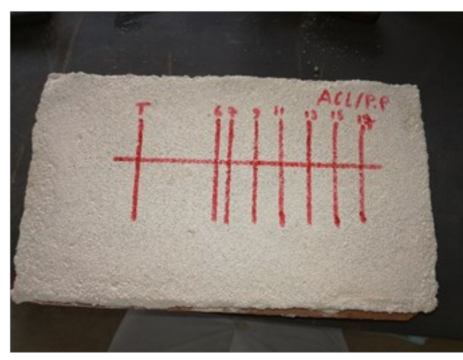

(a)

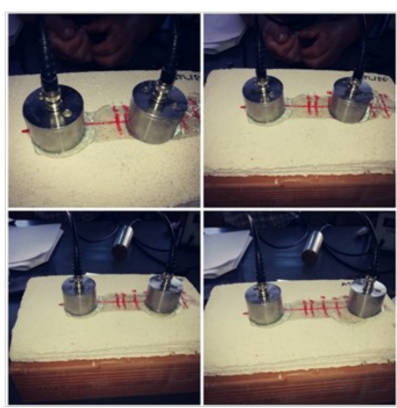

(b)

Figure 4. (a) Marking of ultrasonic pulse velocity (UPV) measuring points in the surface of a coating mortar; (b) measurement process for the same sample.

\subsection{Water Penetration under Low Pressure Test (Karsten Method)}

The water permeability under pressure is an important property to assess in mortars being used as masonry coatings in the rehabilitation of old and historical buildings. This property has been studied in this work according to the Karsten method, which corresponds to RILEM Test Method No. II.4. [34]. When water is applied at a certain pressure to a porous material, it seeps into its microstructure. Therefore, the volume of water that is absorbed during a certain time period is a characteristic of the material and it depends on its porosity [32]. The samples used for the test were mortars applied on ceramic bricks surface as a coating layer, in order to simulate a situation as close to real as possible.

Before preparing the setup of the test, the specimens were dried in a ventilated oven at $60 \pm 5^{\circ} \mathrm{C}$ temperature. Three Karsten tubes with a capacity of $4 \mathrm{ml}$ were fixed to each sample (see Figure 5) using silicone. Prior to initiating the test, it was given $24 \mathrm{~h}$ for silicone drying. Once the tubes were filled withwater, the test started and readings of the amount of water absorbed were taken at $15 \mathrm{~s}, 30 \mathrm{~s}, 1 \mathrm{~min}, 1.5 \mathrm{~min}, 2 \mathrm{~min}, 3 \mathrm{~min}, 4 \mathrm{~min}$, and $5 \mathrm{~min}$. No measurements at later times were noted because in all mortars total water absorption was finished in $5 \mathrm{~min}$ or less. The final result obtained from this test is the absorption coefficient. For each mortar type, three samples were tested at 90 hardening days. 


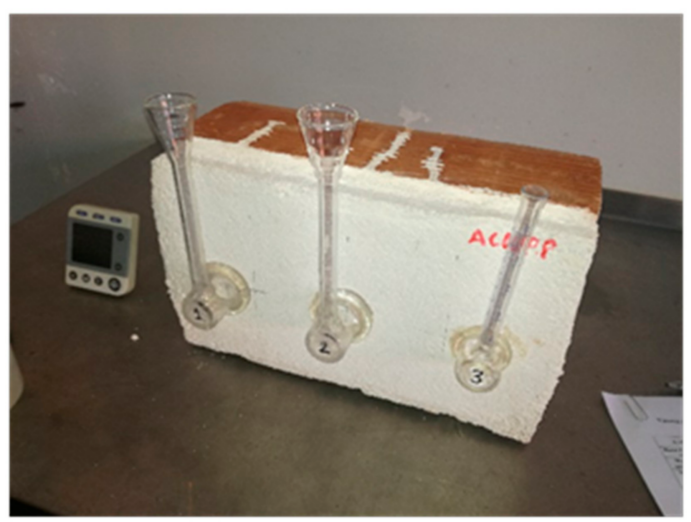

Figure 5. Position of the Karsten tubes in the sample for performing the test.

\subsection{Shrinkage Cracking}

In the specimens of mortars applied on ceramic bricks surface as a coating layer, it has been made a visual evaluation of the possible formation of shrinkage cracks at 28 and 90 hardening days.

\section{Results}

\subsection{Compressive and Flexural Strength}

The compressive strength results obtained are depicted in Figure 6. All the studied mortars showed an increase of this parameter between 28 and 90 days. At 28 days the highest compressive strength was noted for mortars with lime putty and sand (ASPL series), followed by the specimens which incorporated both aerial and hydraulic lime with sand as aggregate (ACL/PP series). On the other hand, the lowest values of compressive strength at 28 days were noted for samples prepared with lime putty, sand, and crushed rock powder (ASPL/PP series). However, the abovementioned ASPL/PP mortars showed the highest compressive strength at 90 hardening days, compared to the other studied series. The values of this parameter were relatively similar for ASPL, ACL/HL, and ACL/PP specimens at 90 days of age, although it was slightly higher for ASPL ones.

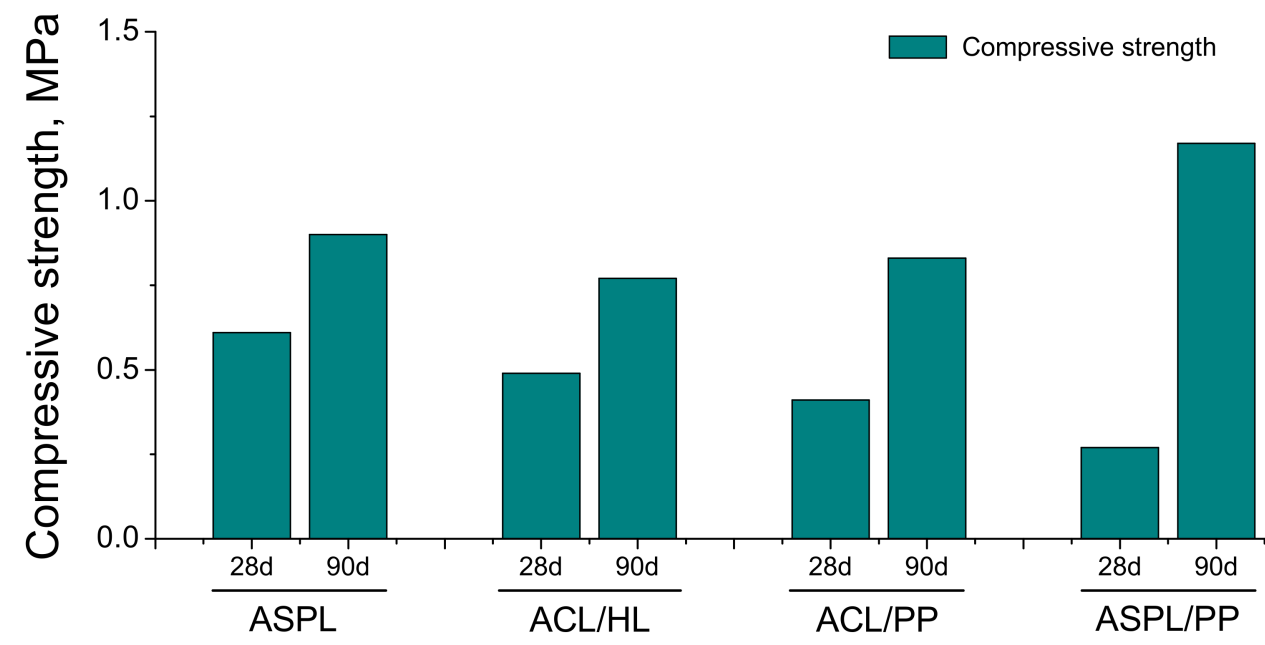

Figure 6. Compressive strength results for the studied mortars.

Regarding the flexural strength, the results of this parameter can be observed in Figure 7. At 28 days, the flexural strength was very similar for ASPL, ACL/HL, and ACL/PP mortars, being lower for ASPL/PP ones. This parameter showed an important increase at 90 hardening days for mortars that incorporate lime putty (ASPL and ASPL/PP series) and this rise was more noticeable for specimens that combined lime putty, sand and 
crushed rock powder (ASPL/PP series). The flexural strength for mortars with aerial lime (ACL/HL and ACL/PP series) was lower compared to mortars with lime putty (ASPL and ASPL/PP series).

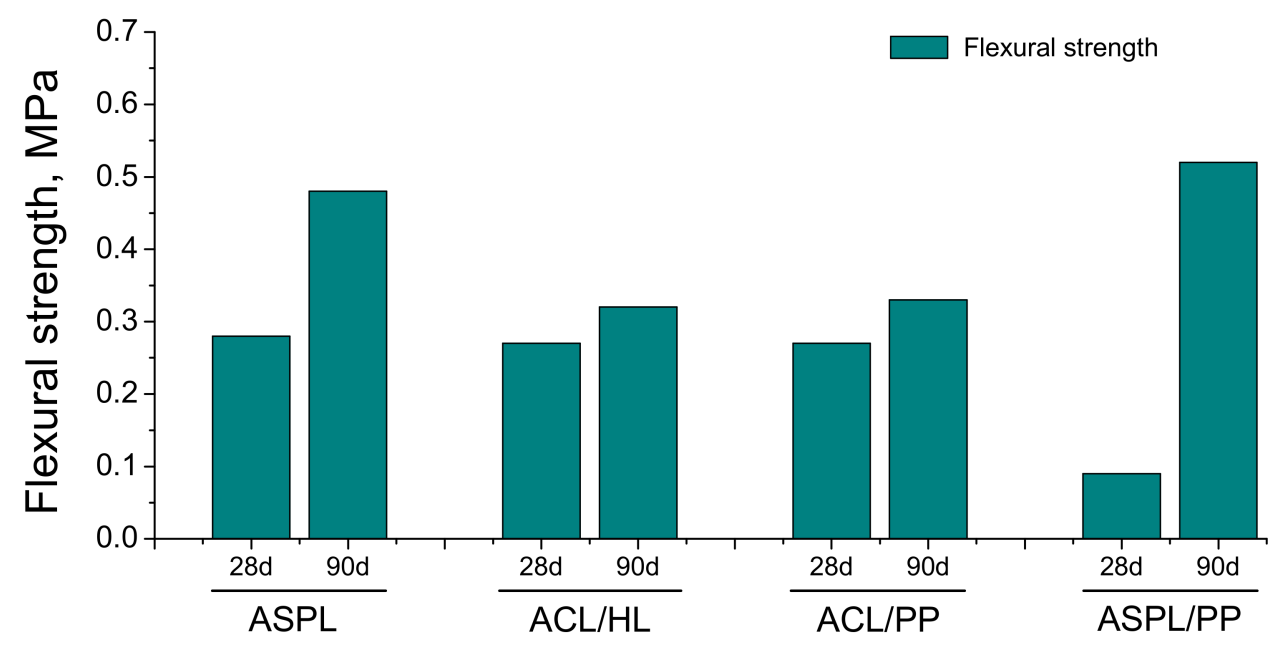

Figure 7. Flexural strengths noted for the different kinds of mortar analyzed.

The ductility coefficient results are represented in Figure 8. For mortars with lime putty, this parameter rose between 28 and 90 days, having a more notable increase for ASPL/PP specimens. On the other hand, the ductility coefficient decreased with age for mortars which included aerial limes (ACL/HL and ACL/PP series). These specimens with aerial lime showed higher values of this coefficient at 28 days, while at 90 days it was slightly greater for mortars with lime putty.

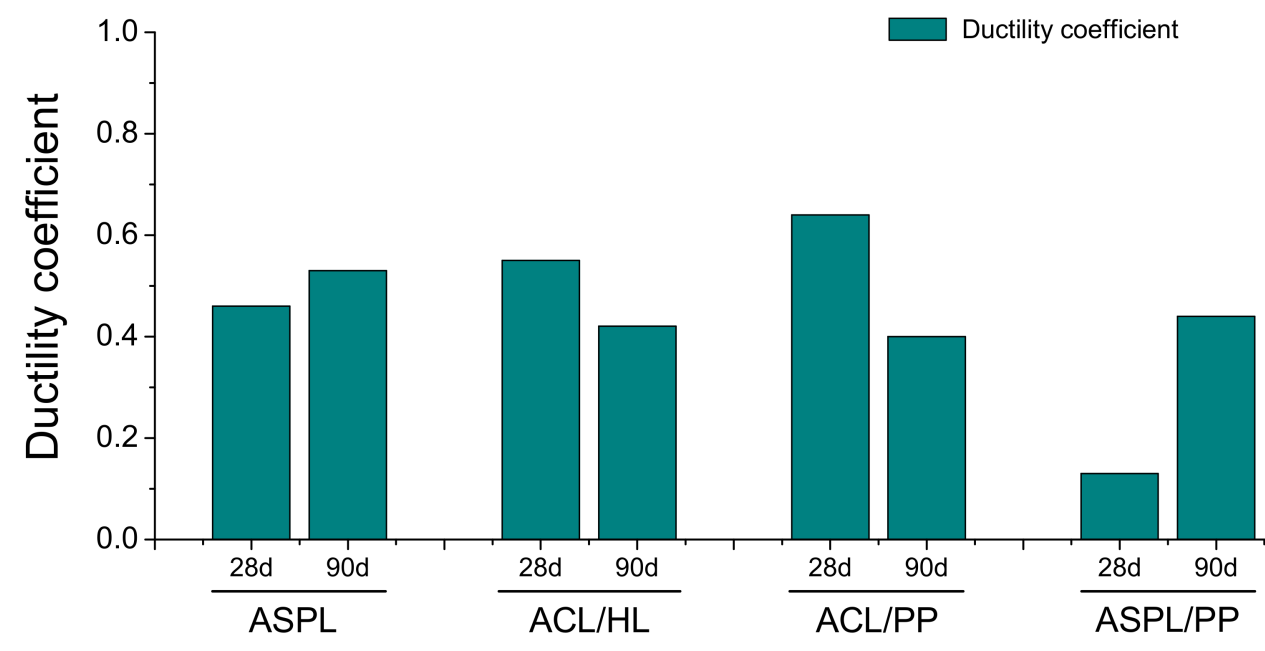

Figure 8. Ductility coefficients for the studied mortars.

\subsection{Pull-off Strength}

All the kinds of mortars showed a cohesive fracture once we finished the pull-off test, as can be seen in Figure 9. The pull-off strength results at 90 days of age are depicted in Figure 10. As can be observed, the highest value of this parameter corresponded to specimens with lime putty, crushed rock powder, and sand (ASPL/PP series), followed by ASPL samples. The pull-off strength was lower for mortars of the series ACL/HL and $\mathrm{ACL} / \mathrm{PP}$ compared to those with lime putty. 

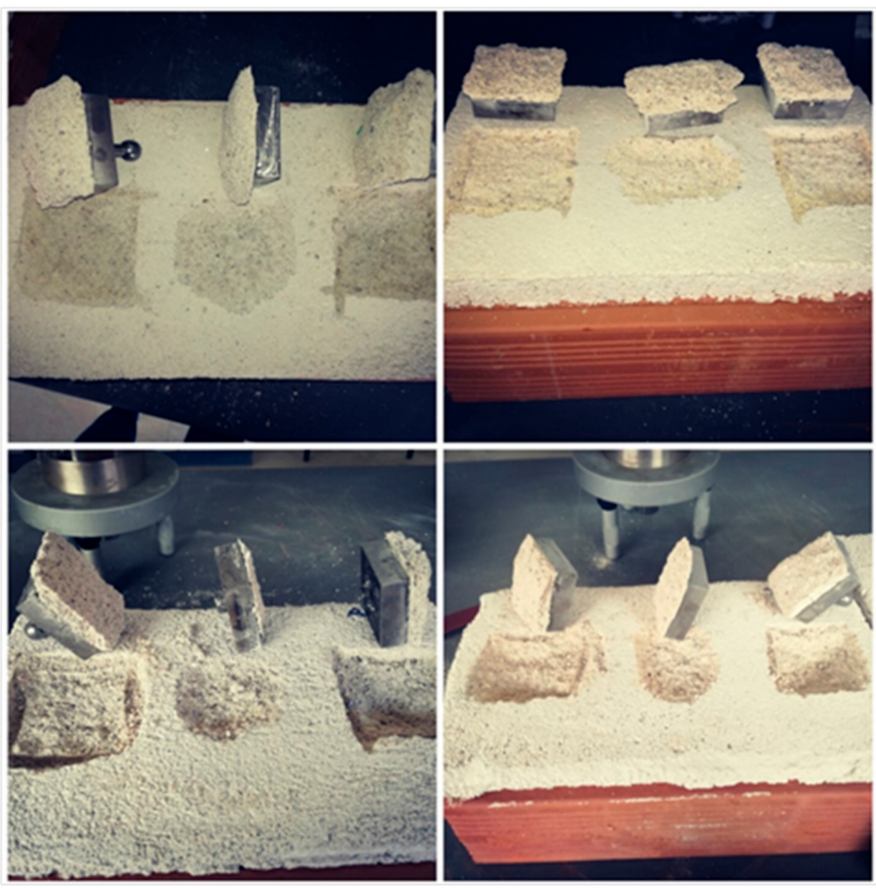

Figure 9. Images of cohesive fractures observed in the studied mortar coatings after performing the pull-off test.

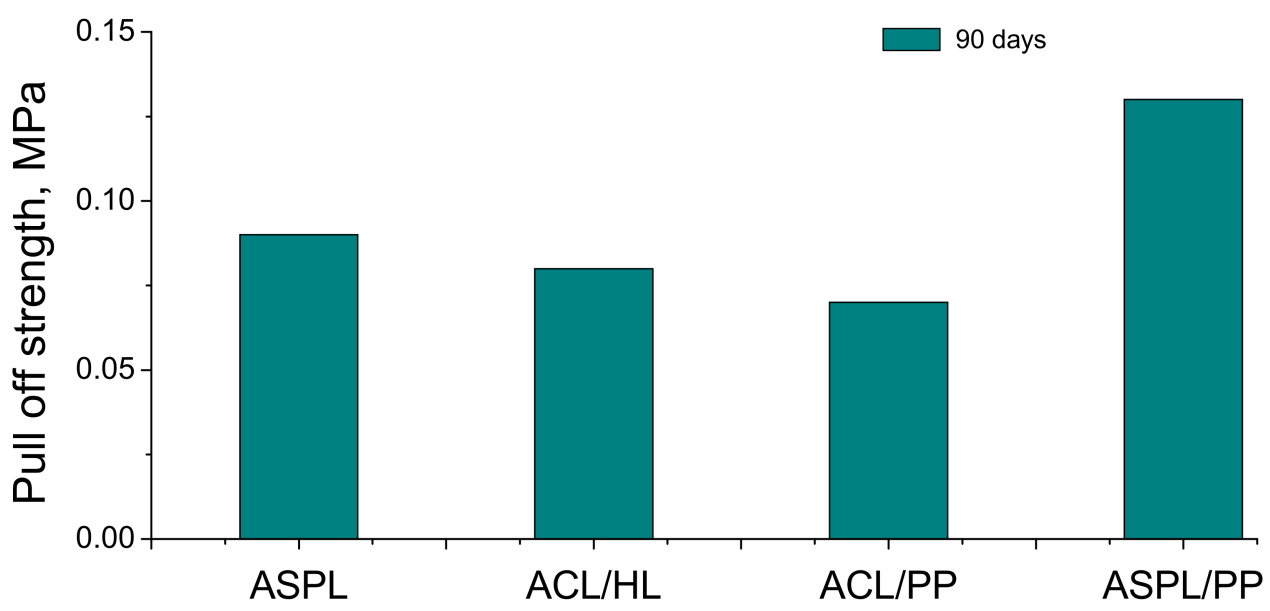

Figure 10. Pull-off strength results for the analyzed mortar coatings at 90 days.

\subsection{Ultrasonic Pulse Velocity}

The ultrasonic pulse velocity was determined for prismatic samples as well as for specimens of mortar coatings on ceramic bricks. The results of this parameter for both types of samples are shown in Figure 11. In general, scarce differences in this parameter were observed for all the studied mortars, which would indicate that they would have a similar porosity, with slight differences.

In relation to the prismatic samples, the ultrasonic pulse velocity was very similar for lime putty mortars (ASPL and ASPL/PP series), although this parameter was higher for mortars with aerial lime and both sand and crushed rock powder as aggregates (ACL/PP series). The lowest ultrasonic pulse velocity was noted for mortars which incorporated both aerial and hydraulic lime (ACL/HL series).

Regarding the specimens consisting of mortar coatings on ceramic bricks, the ultrasonic pulse velocity was very similar for ASPL, ACL/HL, and ASPL/PP series and scarce lower for ACL/PP mortars. 


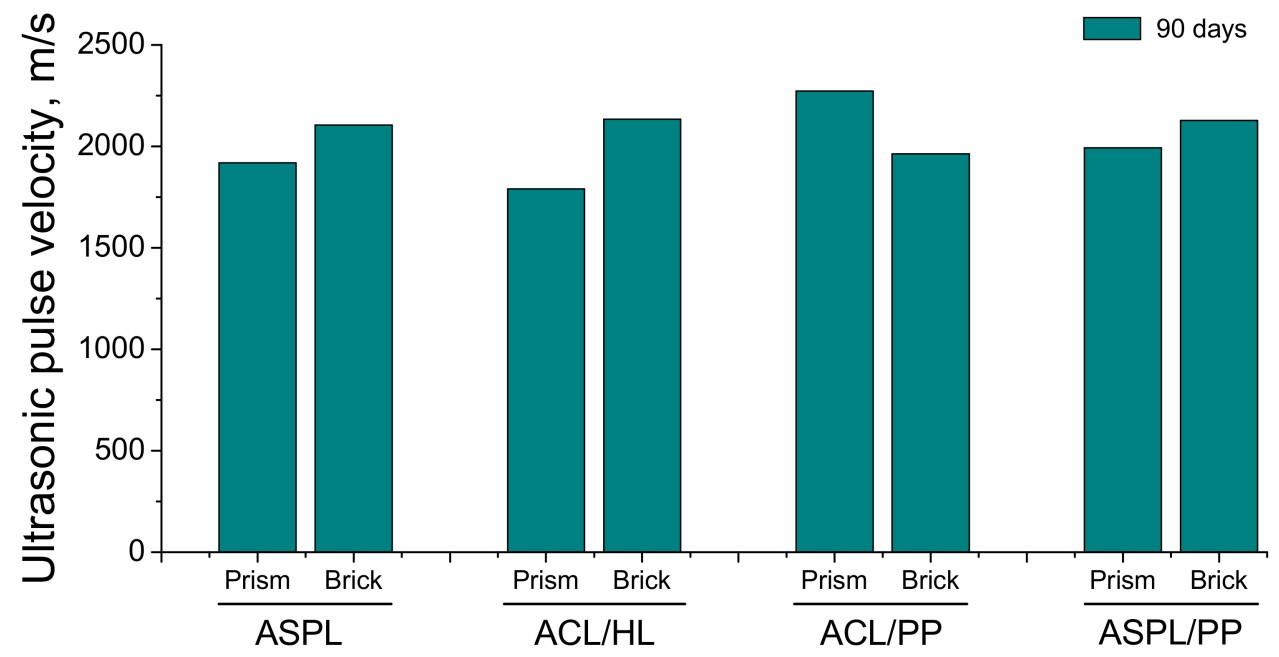

Figure 11. Ultrasonic pulse velocity obtained for prismatic samples (designated as "prism" in the graph) and in mortar coatings on ceramic bricks (designated as "brick" in the graph) at 90 hardening days.

\subsection{Water Penetration under Low Pressure}

The values of the absorption coefficient at 90 hardening days determined using the Karsten method are depicted in Figure 12. The highest coefficients were noted for mortars with lime putty (ASPL and ASPL/PP series), whereas the lowest values of this parameter corresponded to specimens that incorporated aerial lime (ACL/HL and ACL/PP series).

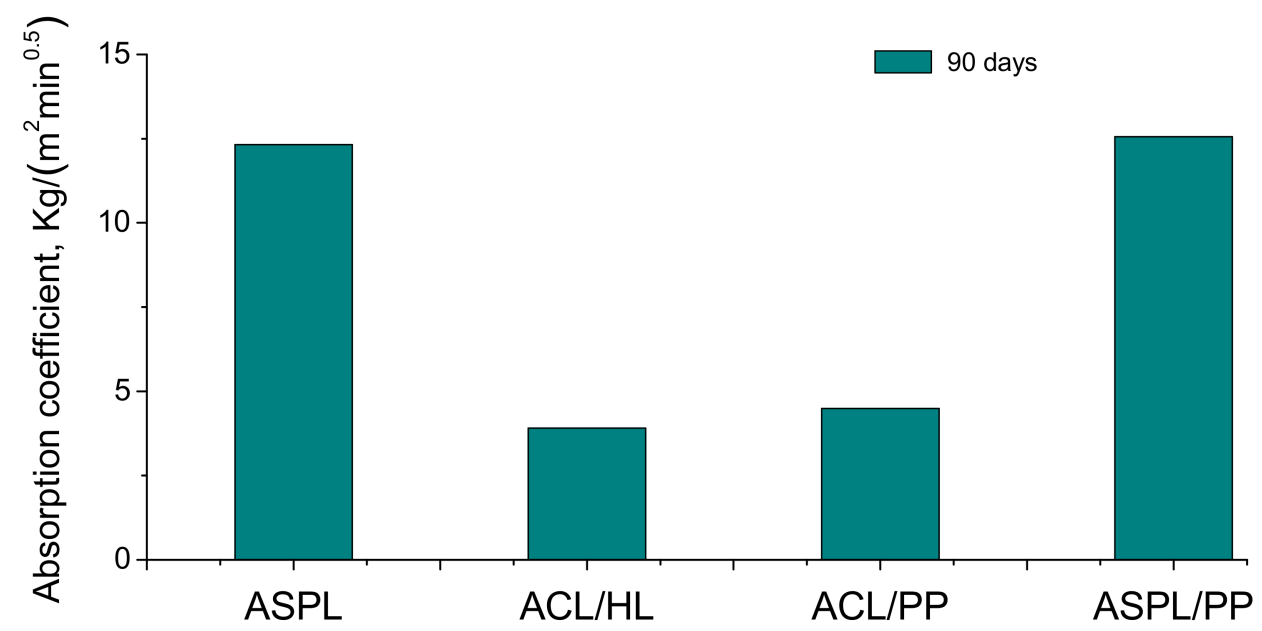

Figure 12. Absorption coefficients at 90 days obtained using the procedure of the Karsten method.

\subsection{Shrinkage Cracking}

The visual evaluation of the specimens of mortars applied on ceramic bricks surface as coating layer did not reveal any formation of shrinkage cracks at 28 and 90 hardening days. Figure 13 shows images of the surfaces of all the mortar's coatings analyzed taken at the age of 90 days. 


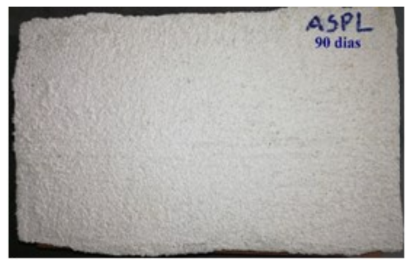

(a)

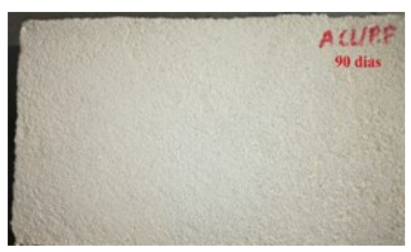

(c)

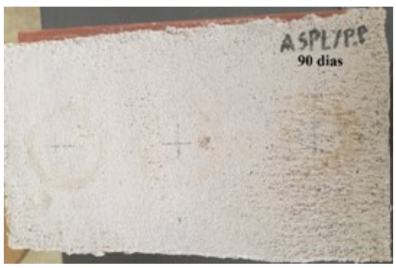

(b)

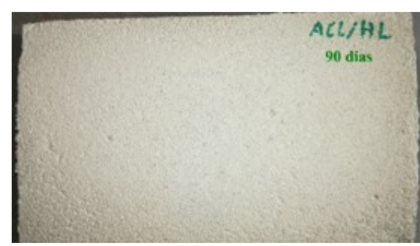

(d)

Figure 13. (a) Surface of lime putty and sand (ASPL) mortar coating specimen at 90 days; (b) surface of lime putty, sand and crushed rock powder (ASPL/PP) mortar coating specimen at 90 days; (c) surface of aerial and hydraulic lime with sand as aggregate (ACL/PP) mortar coating specimen at 90 days; (d) surface of aerial lime, hydraulic lime, and sand (ACL/HL) mortar coating specimen at 90 days.

\section{Discussion}

In view of the results of the compressive and flexural strengths obtained for the studied mortars (see Figures 6 and 7), it seems that the incorporation of crushed rock powder as aggregate produced a reduction of both parameters in the short-term (28 days), although it has a beneficial effect in the middle-term (90 days), improving the mechanical performance, especially when it is combined with lime putty. With respect to the different types of limes studied, in view of the results obtained, the use of lime putty (totally or partially in the binder) overall gave higher strengths after 90 days. This would agree with other authors [11], which noted that the evolution of mechanical properties was slower when aerial lime is used in the binder. Then, specimens with aerial lime would probably need more time than 90 days for reaching similar mechanical strengths than mortars with lime putty. In addition to this, there are authors [14] who also reported that aerial lime binders would reduce the mechanical performance of mortars, in keeping with the results obtained in this work.

On the other hand, the pull-off strength results (see Figure 10) reveal that the incorporation of lime putty produced a beneficial effect in relation to pull-off strength. This result would be in line with other works [12], which pointed out that lime mortars made with putties could improve the general behavior of the mortars. In addition to this, higher pull-off strength has been observed for mortars that combined hydraulic and aerial lime in the binder, in comparison with those made with aerial lime only. This would confirm the beneficial effects of using blended mortars with both aerial and hydraulic lime, also in agreement with other authors [15].

Furthermore, it has been noted that the results of pull-off strength obtained were overall in keeping with those noted for compressive and flexural strengths. In view of that, for checking if there is a direct relation between pull-off and mechanical strengths, a linear fit between compressive and pull-off strengths values obtained for all the mortars studied has been performed (see Figure 14 ), obtaining a $\mathrm{R}^{2}$ value equal to 0.87313 , which would show a good correlation, confirming that higher compressive strength entails higher pull-off strength. The results noted for the pull-off strength were also consistent with those obtained by other authors [35], which reported that the values of this parameter were in the range between 0.61 and $1.66 \mathrm{MPa}$ for mortars applied in external elements of old buildings as plasters and coatings. 


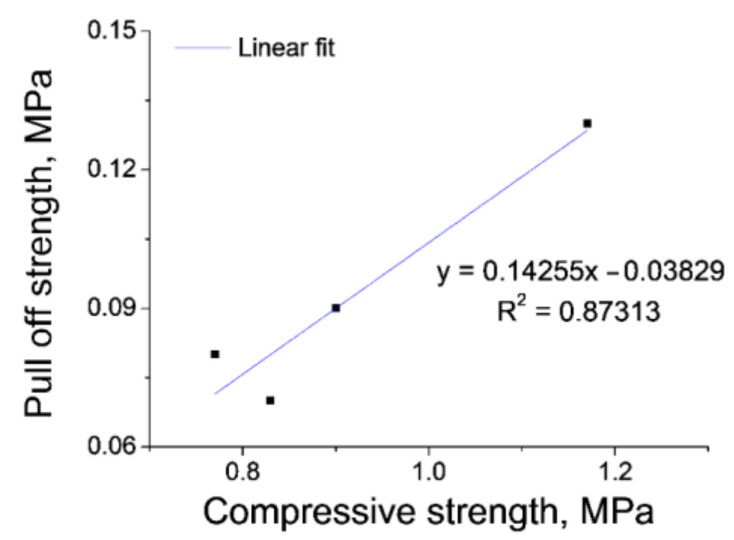

Figure 14. Linear fit between compressive and pull-off strengths values obtained for the studied mortars.

Regarding the ultrasonic pulse velocity, the results obtained in prismatic samples (see Figure 11) would suggest that the mortars with aerial lime and crushed rock powder would be slightly less porous compared to the rest of the mortars studied, while those with both aerial and hydraulic lime would have scarce higher porosity. Several authors have pointed out that the aggregate used in lime mortars has an influence on the porosity and pore size distribution of lime mortars [18], as well as that lime powder mortars generally present higher porosity [10]. Therefore, the possible lower porosity suggested by the ultrasonic pulse velocity results obtained in this work for the studied mortars with aerial lime and crushed rock powder would indicate a beneficial effect of crushed rock powder. Finally, the ultrasonic pulse velocity results obtained in prismatic samples using direct transmission were overall in agreement with those noted for other authors [35,36], which reported values of this parameter between 1340 and $2570 \mathrm{~m} / \mathrm{s}$ for samples made using mortars for applications such as exterior plasters and coatings for old building refurbishment.

In relation to the specimens consisting of mortar coatings on ceramic bricks, the ultrasonic pulse velocity results would indicate that mortars with lime putty and those which combined aerial and hydraulic lime had a similar porosity when they are applied as a coating layer. On the other hand, the ultrasonic pulse velocity results would suggest that coatings made using mortar with aerial lime and crushed rock powder would have a slightly higher porosity. This result differs from that observed for prismatic specimens and it could be due to a possible higher formation of internal shrinkage cracks compared to the rest of the mortars analyzed, although this phenomenon had not been observed in the surface of the specimens with coating layers. The values of ultrasonic pulse velocity for mortar coatings on ceramic bricks from indirect transmission measurements also agreed with other researchers [35,36], which pointed out values of this parameter from 1524 to $2920 \mathrm{~m} / \mathrm{s}$ taken in mortars applied as coatings in surfaces of exterior elements of old buildings [35].

With respect to the water absorption coefficient under low pressure, its results differ from the previously discussed for mechanical properties, for which generally the best performance has been reported for lime putty mortars. The higher absorption coefficients observed for series with lime putty could be related to the possible presence of pores with higher diameters, in spite of having similar or even less global porosity compared to series with aerial lime, as suggested the parameters related to mechanical behavior already described. These pores with higher diameters would facilitate the penetration of water under pressure in the microstructure of the lime putty mortars, giving greater values of the absorption coefficient, as has been noted. In the case of aerial lime series, the possible finer porosity would makethe water penetration more difficult, showing lower absorption coefficients. There are authors [10] who reported that lime putty mortars had a bimodal pore size distribution, with two predominant families of pores with 0.04 and $16.8 \mu \mathrm{m}$ diameters, while lime powder mortars showed a unimodal distribution with the most frequent pore radius at $0.6 \mu \mathrm{m}$. Then, the higher water absorption observed in this work 
for the lime putty mortars analyzed could be explained in relation to the abovementioned presence of a pore family with a relatively high diameter, such as $16.8 \mu \mathrm{m} \mathrm{[10],} \mathrm{which}$ would make the penetration of water under pressure in the microstructure of the material easier. Despite that, the abovementioned possible differences in the pore size distribution of the mortar coatings studied would not noticeably affect their mechanical behavior, as has been shown.

Finally, according to the results obtained, mortar coatings with lime putty presented better mechanical performance, whereas those which incorporate aerial lime in the binder showed better behavior with respect to water absorption under low pressure. However, the general performance noted for all the studied mortars was adequate for their application as coatings of masonry elements in rehabilitation works.

\section{Conclusions}

The main conclusions that can be drawn from the results previously discussed can be summarized as follows:

- The compressive and flexural strengths increased with time for all the studied mortars, being this rise more noticeable for mortars made using lime putty and both sand and crushed rock powder as aggregates (ASPL/PP series). At 90 hardening days, higher values of both mechanical strengths were noted for mortars with lime putty (ASPL and ASPL/PP series) compared to aerial lime ones (ACL/HL and ACL/PP series).

- In view of the results of compressive and flexural strengths, the incorporation of rock crushed powder as an aggregate would produce a reduction of these parameters in the short-term ( 28 days), although it has a beneficial effect in the middle-term (90 days), increasing both mechanical strengths, especially when it is combined with lime putty.

- Regarding the different types of limes studied, the incorporation of lime putty in the binder would generally produce higher compressive and flexural strengths after 90 days.

- With respect to pull-off strength, all the studied mortars showed a cohesive fracture. The results of this parameter were overall in keeping with those noted for compressive and flexural strength, showing the ASPL/PP and ASPL series higher pull-off strength than ACL/HL and ACL/PP ones.

- The ultrasonic pulse velocity was similar for all the studied mortars, which would indicate that they would have a similar global porosity, with slight differences between them.

- The highest absorption coefficients were noted for mortars with lime putty (ASPL and ASPL/PP series). This could be related to the possible presence of pores with higher diameters in these mortars, in spite of having similar or even less global porosity compared to aerial lime mortars (ACL/HL and ACL/PP series), as suggested by the ultrasonic pulse velocity results. These pores with higher diameters would facilitate the penetration of water under pressure in the microstructure of the mortars with lime putty.

- Mortars that incorporated aerial lime (ACL/HL and ACL/PP series) showed the lowest absorption coefficient. This would reveal a finer porosity in these mortars which would make the water penetration more difficult.

- The formation of shrinkage cracks in the surface of the mortar coatings was not detected at 28 and 90 hardening days.

- As a general conclusion, mortar coatings with lime putty (ASPL and ASPL/PP series) showed better mechanical properties, while the mortar coatings with aerial lime (ACL/HL and ACL/PP series) had better behavior regarding water absorption under pressure. Despite that, considering the results obtained in this research, the overall performance of all the studied mortars is adequate for being used in the rehabilitation of masonry elements in old and historical buildings. 
Author Contributions: Conceptualization, F.G.B. and M.d.L.B.; methodology, F.G.B. and M.d.L.B.; investigation, C.M., F.G.B., L.P., M.d.L.B., and J.M.O.; data curation, C.M., F.G.B., M.d.L.B., and J.M.O.; writing - original draft preparation, F.G.B. and J.M.O.; writing-review and editing, L.P. and M.d.L.B.; supervision, F.G.B. and M.d.L.B.; funding acquisition, F.G.B. and J.M.O. This research includes part of the work developed during the research stay of José Marcos Ortega in the ISISEFunctional Performance research group at the Department of Civil Engineering of the University of Coimbra between May and July 2019, under the supervision of Fernando G. Branco. All authors have read and agreed to the published version of the manuscript.

Funding: This work was partially funded through the FCT-Foundation for Science and Technology, IP, within the scope of the R\&D Unit Institute for sustainability and innovation in structural engineering-ISISE (UIDP / 04029/2020), and by the ERDF through the COMPETE 2020 program, Portugal 2020, under the project POCI-01-0247-FEDER-033990 (iNBRail). The APC for publishing this article was funded by the Conselleria de Educación, Investigación, Cultura y Deporte (at present re-named as Conselleria de Innovación, Universidades, Ciencia y Sociedad Digital) de la GeneralitatValenciana (Spain) (grant code GV/2019/070). The research stay of José Marcos Ortega at the University of Coimbra was financially supported in part by the University of Alicante.

Informed Consent Statement: Not applicable.

Conflicts of Interest: The authors declare no conflict of interest.

\section{References}

1. Vinagre, A.I.B. Estudo Comparativo Entre Argamassas de cal Calcítica e de cal Dolomítica: Características Mecânicas, Físicas, Mineralógicas e Microestruturais. Master's Thesis, Universidade de Évora, Évora, Portugal, 2015.

2. Margalha, M.G.; Veiga, M.R.; Brito, J. Algumas vantagens do uso da cal em pasta em revestimentos. In Proceedings of the $2^{\circ}$ Encontro sobre Patologia e Reabilitação de Edifícios-PATORREB, Porto, Portugal, 20-21 March 2006.

3. Coelho, A.Z.G.; Torgal, F.P.; Jalali, S. A Cal na Construção; TecMinho: Guimarães, Portugal, 2009.

4. Veiga, R. Air lime mortars: What else do we need to know to apply them in conservation and rehabilitation interventions? A review. Constr. Build. Mater. 2017, 157, 132-140. [CrossRef]

5. Veiga, R.; Santos Silva, A. Mortars. In Long-term Performance and Durability of Masonry Structures; Ghiassi, B., Lourenço, P.B., Eds.; Woodhead Publishing Series in Civil and Structural Engineering; Woodhead Publishing: Duxford, UK, 2019 ; pp. 169-208.

6. Moropoulou, A.; Maravelaki-Kalaitzaki, P.; Borboudakis, M.; Bakolas, A.; Michailidis, P.; Chronopoulos, M. Historic mortars technologies in Crete and guidelines for compatible restoration mortars. In PACT, Revue du Groupe Europeen d'etudes pour les Techniques Physiques, Chimiches, Biologiques et Mathematiques Applique's a L'archeologie, Compatible Materials for the Protection of European Cultural Heritage; Biscontin, G., Moropoulou, A., Erdik, M.J.D.R., Eds.; Technical Chamber of Greece: Athens, Greece, 1998; Volume 55, pp. 55-72.

7. Aalil, I.; Badreddine, D.; Beck, K.; Brunetaud, X.; Cherkaoui, K.; Chaaba, A.; Al-Mukhtar, M. Valorization of crushed bricks in lime-based mortars. Constr. Build. Mater. 2019, 226, 555-563. [CrossRef]

8. Thirumalini, S.; Ravi, R.; Rajesh, M. Experimental investigation on physical and mechanical properties of lime mortar: Effect of organic addition. J. Cult. Herit. 2018, 31, 97-104. [CrossRef]

9. Maravelaki-Kalaitzaki, P.; Bakolas, A.; Karatasios, I.; Kilikoglou, V. Hydraulic lime mortars for the restoration of historic masonry in Crete. Cem. Concr. Res. 2005, 35, 1577-1586. [CrossRef]

10. Aggelakopoulou, E.; Bakolas, A.; Moropoulou, A. Lime putty versus hydrated lime powder: Physicochemical and mechanical characteristics of lime based mortars. Constr. Build. Mater. 2019, 225, 633-641. [CrossRef]

11. Garijo, L.; Zhang, X.; Ruiz, G.; Ortega, J.J. Age effect on the mechanical properties of natural hydraulic and aerial lime mortars. Constr. Build. Mater. 2020, 236, 117573. [CrossRef]

12. Faria, P.; Henriques, F.; Rato, V. Comparative evaluation of lime mortars for architectural conservation. J. Cult. Herit. 2008, 9 , 338-346. [CrossRef]

13. Silva, B.A.; Ferreira Pinto, A.P.; Gomes, A. Natural hydraulic lime versus cement for blended lime mortars for restoration works. Constr. Build. Mater. 2015, 94, 346-360. [CrossRef]

14. Gulbe, L.; Vitina, I.; Setina, J. The Influence of Cement on Properties of Lime Mortars. Procedia Eng. 2017, 172, 325-332. [CrossRef]

15. Silva, B.A.; Ferreira Pinto, A.P.; Gomes, A. Influence of natural hydraulic lime content on the properties of aerial lime-based mortars. Constr. Build. Mater. 2014, 72, 208-218. [CrossRef]

16. Grilo, J.; Faria, P.; Veiga, R.; Santos Silva, A.; Silva, V.; Velosa, A. New natural hydraulic lime mortars-Physical and microstructural properties in different curing conditions. Constr. Build. Mater. 2014, 54, 378-384. [CrossRef]

17. Grilo, J.; Santos Silva, A.; Faria, P.; Gameiro, A.; Veiga, R.; Velosa, A. Mechanical and mineralogical properties of natural hydraulic lime-metakaolin mortars in different curing conditions. Constr. Build. Mater. 2014, 51, 287-294. [CrossRef]

18. Santos, A.R.; Veiga, M.D.R.; Santos Silva, A.; de Brito, J.; Álvarez, J.I. Evolution of the microstructure of lime based mortars and influence on the mechanical behaviour: The role of the aggregates. Constr. Build. Mater. 2018, 187, 907-922. [CrossRef] 
19. Zhang, Z.J.; Liu, J.B.; Li, B.; Yu, G.X.; Li, L. Experimental study on factors affecting the physical and mechanical properties of shell lime mortar. Constr. Build. Mater. 2019, 228. [CrossRef]

20. Gameiro, A.; Santos Silva, A.; Faria, P.; Grilo, J.; Branco, T.; Veiga, R.; Velosa, A. Physical and chemical assessment of limemetakaolin mortars: Influence of binder:aggregate ratio. Cem. Concr. Compos. 2014, 45, 264-271. [CrossRef]

21. Garijo, L.; Zhang, X.; Ruiz, G.; Ortega, J.J.; Wu, Z. The effects of dosage and production process on the mechanical and physical properties of natural hydraulic lime mortars. Constr. Build. Mater. 2018, 169, 325-334. [CrossRef]

22. Instituto Português da Qualidade. NP EN 933-1. Ensaios das Propriedades Geométricas dos Agregados-Parte 1: Análise Granulométrica, Método da Peneiração; Instituto Português da Qualidade: Lisboa, Portugal, 2014.

23. Instituto Português da Qualidade. NP EN 1097-6. Ensaios das Propriedades Mecânicas e Físicas dos Agregados, Parte 6: Determinação da Massa Volúmica e da Absorção de Água; Instituto Português da Qualidade: Lisboa, Portugal, 2016.

24. Instituto Português da Qualidade. NP EN 1097-3. Ensaios das Propriedades Mecânicas e Físicas dos Agregados, Parte 3: Determinação da Baridade e do Volume de Vazios; Instituto Português da Qualidade: Lisboa, Portugal, 2002.

25. Instituto Português da Qualidade. NP EN 459-1. Cal de Construção-Parte 1: Definições, Especificações e Critérios de Conformidade; Instituto Português da Qualidade: Lisboa, Portugal, 2015.

26. European Committee for Standardization. EN 1015-2. Methods of Test for Mortar for Masonry_Part 2: Bulk Sampling of Mortars and Preparation of test Mortars; Instituto Português da Qualidade: Brussels, Belgium, 1999.

27. European Committee for Standardization. EN 1015-3. Methods of Test for Mortar for Masonry—Part 3: Determination of Consistence of Fresh Mortar (by Flow Table); Instituto Português da Qualidade: Brussels, Belgium, 2000.

28. European Committee for Standardization. EN 1015-11. Methods of Test for Mortar for Masonry-Part 11: Determination of Flexural and Compressive Strength of Hardened Mortar; Instituto Português da Qualidade: Brussels, Belgium, 1999.

29. Pavão, J.M. Estudo da Influência da Dosagem de Ligante no Desempenho de Rebocos para Edifícios Antigos. Master's Thesis, Universidade Técnica de Lisboa, Lisboa, Portugal, 2010.

30. European Committee for Standardization. EN 1015-12. Methods of Test for Mortar for Masonry—Part 12: Determination of Adhesive Strength of Hardened Rendering and Plastering Mortars on Substrates; European Committee for Standardization: Brussels, Belgium, 2000.

31. da Encarnação Ferreira, M.J. Análise das Características Mecânicas de Amostras de Argamassas Pré-Doseadas. Master's Thesis, Técnico de Lisboa, Lisboa, Portugal, 2012.

32. de Viveiros Mendonça, B. Estudo do Desempenho das Argamassas Hidráulicas-Influência do Ligante. Master's Thesis, Universidade Técnica de Lisboa, Lisboa, Portugal, 2007.

33. Instituto Português da Qualidade. NP EN 12504-4. Ensaios do Betão nas Estruturas, Parte 4: Determinação da Velocidade de Propagação dos Ultra-Sons; Instituto Português da Qualidade: Lisboa, Portugal, 2007.

34. RILEM Commision 25-PEM. Measurement of Water Absorption Under Low Pressure; Rilem Test Method No. II.4; RILEM Commision: Bagneux, France, 1980.

35. Gomes, F.A.C.M. Argamassas Pré-Doseadas para Rebocos de Edificios Antigos. Master's Thesis, Universidade Técnica de Lisboa, Lisboa, Portugal, 2009.

36. Agostinho, C.S.A. Estudo da Evolução do Desempenho no Tempo de Argamassas de cal Aérea. Master's Thesis, Universidade Técnica de Lisboa, Lisboa, Portugal, 2008. 